\title{
Pengembangan Model Pembelajaran Sejarah Wisata Negeri Dongeng Berbasis Taman Miniatur Melalui Pendekatan Outdoor Study di SMA Negeri Ponggok Blitar
}

\author{
Developing A Model Of Learning History Based On The Fairy Tale \\ Miniature Park With The Outdoor Study in SMA Negeri Ponggok Blitar
}

\author{
Fandu Dyangga Pradeta M.Pd ${ }^{1}$, Novi Catur Muspita M.Si ${ }^{2}$ \\ ${ }^{1}$ Fakultas Ilmu Sosial dan Politik, Universitas Islam Balitar \\ Jl. Majapahit No.2-4 Blitar, Indonesia \\ ${ }^{2}$ Fakultas Ilmu Sosial dan Politik, Universitas Islam Balitar \\ Jl. Majapahit No.2-4 Blitar, Indonesia \\ E-mail: pradetafandu@gmail.com
}

\begin{abstract}
ABSTRAK
Pembelajaran sejarah menjadi salah satu pelajaran yang dituntut untuk dapat memberikan nilai kearifan dan pendidikan karakter pada peserta didik sebagai bentuk jawaban dari tantangan perkembangan globalisasi saat ini. Dalam penelitian ini peneliti mencoba untuk melakukan sebuah inovasi pembelajaran dengan menerapkan pengembangan model pembelajaran sejarah berbasis obyek wisata Taman Miniatur Negeri Dongeng yang ada di Desa Ponggok Kabupaten Blitar. Penelitian ini bertujuan; (1) Mendeskripsikan kondisi Pembelajaran Sejarah di SMA Negeri Ponggok. (2) Mengembangkan model pembelajaran sejarah berbasis Taman Miniatur Negeri Dongeng dengan pendekatan Outdoor Study. (3) Melakukan uji efektivitas model pembelajaran sejarah berbasis Taman Miniatur Negeri Dongeng dengan pendekatan Outdoor Study. Penelitian ini didasarkan pada kriteria penelitian pengembangan (R\&D) dengan desain pembelajaran Model ADDIE. Penelitian ini dibagi menjadi 3 tahap pelaksnaan yaitu; tahap pendahuluan, tahap pengembangan model dan tahap terakhir uji efektivitas. Penelitian ini menghasilkan buku Ajar Monograf dan HKI sebagai luaran tambahan dan luaran wajib terbit di Jurnal Terakreditasi Nasional yaitu Translitera. Hasil penelitian ini dapat dilihat bahwa ada perbedaan hasil belajar antara kelas Kontrol (XI IPS 1) dengan kelas Eksperimen XI IPS 3) yang bisa dilihat dari hasil uji coba pada setiap tahapnya. Berdasarkan hasil uji statistik hitung SPSS dapat disimpulkan bahwa, model pembelajaran sejarah berbasis wisata negeri dongeng dapat digunakan untuk mencapai efektivitas belajar siswa.
\end{abstract}

Kata Kunci : Pengembangan Model, Sejarah, Wisata, Negeri Dongeng

\section{ABSTRACT}

History learning is one of the lessons that are required to be able to provide wisdom value and character education to students as a form of response to the challenges of the current development of globalization. In this study, the researchers tried to carry out a learning innovation by applying the development of a historical learning model based on the tourism object of the Fairy Tale 
Miniature Park in Ponggok Village, Blitar Regency. The purpose of this research; (1) Describe the condition of the History Learning in SMA Negeri Ponggok. (2) Developing a model of learning history based on the Fairy Tale Miniature Park with the Outdoor Study approach. (3) To test the effectiveness of the historical learning model based on the Fairy Tale Miniature Park with the Outdoor Study approach. This research is based on the criteria for research and development $(R \& D)$ with the ADDIE Model learning design. This research is divided into 3 stages of implementation, namely; the preliminary stage, the model development stage and the final stage of the effectiveness test. This research resulted in the textbook Monograph and HKI as an additional output and mandatory output to be published in a National Accredited Journal, namely Translitera. The results of this study can be seen that there are differences in learning outcomes between the Control class (XI IPS 1) and the Experiment class XI IPS 3) which can be seen from the results of the trials at each stage. Based on the results of the SPSS count statistical test, it can be concluded that the history learning model based on fairy tale tourism can be used to achieve student learning effectiveness.

Keywords: Model Development, History, Tourism, Fairy Tale

\section{PENDAHULUAN}

Melihat kondisi pembelajaran saat ini yang memprihatinkan karena situasi pandemi Covid 19, maka perlunya pembaharuan atau alternatif pembelajaran sejarah yang inovatif. Pembelajaran sejarah seharusnya mulai dikaitkan dengan potensi kekayaan obyek wisata yang ada di setiap wilayah daerah tertentu. Kabupaten Blitar merupakan wilayah yang terkenal cukup popular dengan destinasi baik wisata sejarah maupun wisata alamnya. Wisata yang ada di Kota Blitar ini yang terbaru adalah wisata edukasi Negeri Dongeng Taman Miniatur Landmark.

Untuk mempermudah dalam mengkaji tentang pembelajaran sejarah berbasis Wisata Negeri Dongeng ini, diperlukan sebuah model yang dapat membuat siswa lebih efektif dalam melakukan pembelajaran dari rumah. Maka dalam penelitian ini akan menggunakan metode pembelajaran diluar kelas (Outdoor Study), untuk mengarahkan siswa melakukan aktivitas mengamati lingkungan sekitar sesuai dengan materi yang diajarkan. Akan tetapi dalam penelitian ini berhubung kondisi yang tidak memungkinkan karena situasi pandemi, maka pembelajaran dilaksanakan dari rumah (Online). Sehingga diharapkan siswa tetap berada di rumah dengan mengikuti instruksi guru melalui media Handphone sebagai sarana komunikasi. Dalam proses pelaksanaan 
pembelajaannya nanti, peneliti juga menggunakan model desain pengembangan tipe ADDIE untuk mempermudah dalam langkah penerapannya.

Penerapan pembelajaran saat ini seharusnya diarahkan untuk lebih kreatif dalam mengkombinasikan suatu metode pembelajaran yang dapat membuat siswa memiliki semangat dan minat belajar yang tinggi. Salah satu cara yang dilakukan dengan mengambil suatu tema terkait pemanfaatan obyek wisata sebagai sumber pembelajaran siswa dengan materi yang diinput dari bangunan sejarah berbasis taman miniatur 7 keajaiban dunia.

Tujuan Penelitian ini adalah 1). Mendeskripsikan kondisi awal pembelajaran sejarah di SMA Negeri Ponggok Blitar. 2) Mengembangkan model pembelajaran sejarah berbasis Taman Miniatur Negeri Dongeng. 3) Menguji efektivitas penerapan model pembelajaran sejarah berbasis Taman Miniatur Negeri Dongeng dengan menggunakan pendekatan Outdoor Study. Selain itu Adapun alasan mengapa penelitian ini dilakukan yaitu; 1) Untuk memberikan sumbangan informasi secara ilmiah mengenai pengembangan sumber belajar sejarah siswa berbasis Taman Miniatur Negeri Dongeng dengan pendekatan Outdoor Study. 2) Diharapkan pendidik dapat mengembangkan materi pembelajaran sejarah dengan model - model lain yang kreatif dan inovatif. 3) Untuk mendorong siswa agar termotivasi dan aktif dalam mengembangkan potensi akademiknya dengan menggali pengetahuan dan wawasan dengan memanfaatkan media belajar diluar sekolah 4) Penelitian ini dapat memberikan arsip dokumen sebagai bahan rujukan dan untuk bahan pengembangan penelitian yang akan datang.

\section{METODE PENELITIAN}

Tempat penelitian di SMA Negeri Ponggok Kabupaten Blitar dan subjek dalam penelitian ini adalah kelas XI IPS. Dasar pemilihan subyek uji coba ini ditujukan karena sesuai dengan kondisi siswa dan lingkungan belajarnya (hasil rekomendasi dari guru kelas). Pada awalnya peneliti menerapkan alternatif model pembelajaran eksperimen dengan melakukan kunjungan pada obyek wisata setempat untuk melihat efektifitas pembelajaran yang berbasis Taman Miniatur Negeri Dongeng. Berhubung kondisi pandemic seperti ini pembelajaran hanya boleh dilakukan di rumah dengan sistem online. 
Dalam pelaksanaannya penelitian ini tergolong jenis riset pengembangan Research and Development (R\&D) dengan desain pembelajaran Model ADDIE. Adapun langkah- langkah pengembangan model desain pembelajaran ADDIE yang peneliti gunakan, yaitu (a) analysis, (b) desain, (c) development, (d) implementaion, dan (e) evaluation. Pendekatan yang digunakan dalam penelitian ini adalah "Outdoor Study" yang sudah tersusun dalam pengembangan sintaks pembelajaran. Akan tetapi dalam prakteknya sistem pembelajaran di luar kelas ini tidak langsung menuju ke lokasi wisata, akan tetapi para siswa diberikan ilustrasi gambar atau foto terkait materi yang diajarkan. Penelitian pengembangan ini merupakan perpaduan antara metode kualitatif (hasil aktivitas pembelajaran) dan kuantitatif (hasil belajar). Pengembangan model pembelajaran ini diterapkan sebagai bentuk alternatif eksperimen untuk membuat desain pembelajaran yang baru untuk dunia pendidikan saat ini.

\section{Prosedur Penelitian}

1) Tahap I : Analisis Kebutuhan (Studi Pendahuluan)

Rincian kegiatan yang dilakukan sebagai berikut antara lain: (a) Studi literatur (b) Studi pustaka dan (c) berdasarkan deskripsi temuan dan kebutuhan model guru dan siswa di lapangan dilengkapi dengan berbagai teori dan konsep guna menyusun protoype model pengembangan obyek wisata Negeri Dongeng. Pada tahap ini peneliti sudah memiliki gambaran tentang bagaimana pelaksanaan pembelajaran nanti dilakukan.

2) Tahap II : Pengembangan Model

Tahap ini untuk pengembangan prototype model menjadi model berbasis Taman Miniatur Landmark dengan menggunakan pendekatan Outdoor Study yang meliputi; validasi desain, perbaikan desain, uji coba luas. Dalam tahap ini, prosedur pelaksanaan sudah dilakukan dengan beberapa tahap sekaligus memberikan evaluasi terhadap desain model pembelajaran. Pada tahap ini juga sudah bisa dilihat peningkatan hasil belajar siswa yang diberikan perlakuan (kelas eksperimen XI IPS 3).

3) Tahap III : Evaluasi (Uji Efektivitas Model)

Tujuan tahap uji efektifitas model adalah untuk mengetahui keefektifan model baru yang sudah dikembangkan dengan obyek wisata dengan pendekatan 
Outdoor Study di SMAN 1 Ponggok kelas XI IPS di Kabupaten Blitar. Teknik analisis data menggunakan uji validitas dan uji reabilitas dengan tes prestasi dan tes angket. Selain itu juga akan dilakukan uji normalitas digunakan untuk menguji skor hasil tes soal. Uji homogenitas digunakan untuk menguji kesamaan varian antara dua kelompok yang dibandingkan. Pada tahap ini sudah bisa dilihat bagaimana perbandingan hasil belajar kelas kontrol (kelas XI IPS 1) dengan kelas eksperimen (kelas XI IPS 3).

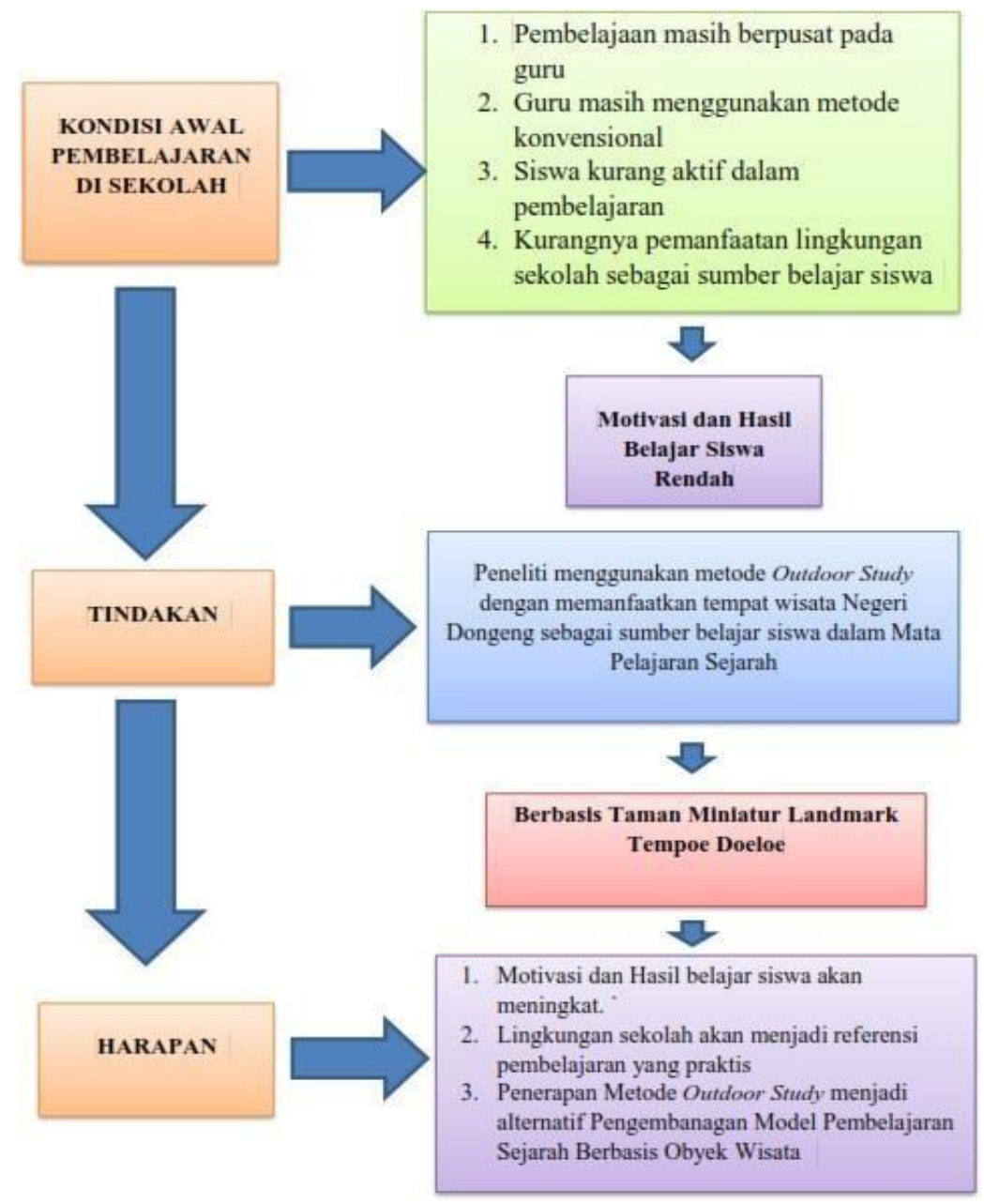

Gambar 1. Prototype model pengembangan obyek wisata Negeri Dongeng (diolah peneliti, 2020)

\section{HASIL DAN PEMBAHASAN}

\section{Hasil Penelitian Pendahuluan}

Berdasarkan hasil dari studi pendahuluan, pembelajaran yang dilakukan pada situasi daring ini memang menjadi kendala baik bagi pendidik maupun peserta didik. Hal ini cukup sulit apabila pembelajaran dituntut untuk memperoleh 
hasil maksimal. Kendala yang dialami terjadi pada semua kelas yang diajar pada kelas jarak jauh. Hal ini membuat pendidik harus kreatif dalam melakukan terobosan atau menemukan alternative solusi yang efektif. Makadari tu dalam penelitian ini peneliti mencoba mengangkat tema sector wisata yang menjadi favorit kalangan masyarakat. Pembelajaran ini awalnya diharapkan bisa dilakukan denga meotde outdoor study dengan langsung meninjau lokasi wisata edukasi berbasis negeri dongeng. Akan tetapi berhubung adanya wabah virus Corona semua menjadi berubah. Metode pembelajaran dibuat dengan konsep daring dengan menggunakan media WA group sebagai solusi yang sederhana. Dengan ini diharapkan pembelajaran akan tetap berjalan efektif tanpa mengurangi esensi dari tujuan pembelajaran.

\section{Hasil Pengembangan Model Pembelajaran}

Pada tahap pengembangan model pembelajaran sejarah diharapkan peserta didik mampu menganalisis proses masuk dan perkembangan penjajahan bangsa Eropa ke Indonesia dengan materi tentang Kolonialisme dan Imperialisme. Pemilihan tema dan materi ini disesuaikan dengan kajian yang ada di dalam obyek wisata negeri dongeng yang mengusung konsep bangunan miniatur 7 keajaiban dunia.

Secara singkat pada tahap ini pengembangan model dilakukan 3 tahap uji coba. Melihat dari perkembangan itu terjadi peningkatan pada setiap tahapnya. Melalui pengembangan model pembelajaran sejarah berbasis wisata negeri dongeng, siswa lebih mudah melihat dan menganalisis dengan mengkaitkan peristiwa yang terjadi saat itu dengan capaian yang ada dengan perkembangan teknologi dan bangunan miniature keajaiban dunia. Sehingga mereka lebih memahami bagaimana mempelajari sejarah dengan makna peristiwa yang saling berkorelasi khususnya bangunan megah yang tersebar di dunia. Pelaksanaan pembelajaran dengan metode daring memberikan suasana pembeda bagi pendidik dan peserta didik.

Pembelajaran memang dirasa menyulitkan karena dalam pelaksanaan diskusinya harus online, secara praktek banyak menemukan kesulitan dan kerumitan dalam mengatur jalankan pembelajaran terutama saat diskusi berlangsung. Akan tetapi dengan apapun kondisinya diskusi tetap berjalan untuk 
mrmperoleh tujuan dan manfaat dari proses belajar secara jarak jauh. Hal ini menjadi pengalaman baru dalam memberikan pembelajaran dengan alternative solusi yang membuat peserta didik tetap antusias.

\section{Hasil Uji Efektivitas Model Pembelajaran}

Hasil uji efektifitas menunjukkan bahwa model pembelajaran berbasis Wisata Negeri Dongeng yang dipadukan dengan pendekatan dan model pembelajaran yang sudah ada, menunjukkan prestasi belajar kelas eksperimen (dilakukan perlakuan) memiliki hasil yang lebih baik dbandingkan dengan kelas kontrol (model pembelajaran biasa). Berdasarkan hasil uji rerata untuk kelas kontrol yaitu pre tes 34.29 dan pos tes 71.14. Sedangkan Uji T sebesar 16.477 dengan taraf signifikansi $0,000<0,25$ maka Ho ditolak, sehingga rerata sebelum dan sesudah perlakuan kelas kontrol tidak sama. Berdasarkan hasil uji rerata untuk kelas eksperimen yaitu pre tes 32.86 dan pos tes 75.14. Sedangkan Uji T sebesar 19.125 dengan taraf signifikansi $0,000<0,25$ maka Ho ditolak, sehingga rerata sebelum dan sesudah perlakuan kelas eksperimen tidak sama. Dapat disimpulkan dari hasil data ini maka, penerapan model pembelajaran yang digunakan dengan berbasis obyek wisata sejarah dapat mencapai efektifitas belajar siswa.

\section{KESIMPULAN DAN SARAN}

Hasil dari pelaksanaan ini menjelaskan bahwa ada peningkatan hasil belajar siswa di kelas. Secara umum siswa juga mengatakan bahwa model yang diterapkan sudah bagus sesuai dengan tujuan pembelajaran yang dilakukan. Dalam pelaksanaannya peserta didik juga senang, karena cara penyampaian materi juga menggunakan ilustrasi gambar foto dari bangunan yang ada di wisata negeri dongeng yang ada di Ponggok. Materi yang disampaikan juga dirasa menarik, karena materi pembelajaranya belum pernah diajarkan sebelumnya. Mereka juga mengharapkan bahwa pembelajaran juga perlu mengkaitkan materi dengan wisata atau nilai kearifan local yang ada di sekitar wilayah mereka. Selain itu pembelajaran jarak jauh juga memerlukan alokasi waktu dan manajemen diskusi yang bagus. Walaupun dalam pelaksanaannya juga masih kurang efektif, akan tetapi materi dan tujuan pembelaran sudah tersalurkan dengan baik.

Selain itu hasil evaluasi pengembangan model pembelajaran ini dapat dilihat 
peningkatannya pada hasil penilaian kelompok dan hasil post test diakhir pembelajaran. Dapat disimpulkan bahwa penggunaan model pembelajaran dengan pendekatan Outoor Study dengan sistem daring cukup efektif dalam proses pembelajaran di jarak jauh, terbukti dengan peningkatan hasil belajar. Untuk selanjutnya masih ada tahap revisi lagi untuk dilanjutkan pada pelaksanaan tahap akhir yaitu tahap uji efektivitas model sebagai hasil akhir pengembangan model pembelajaran.

\section{Saran}

\section{Bagi Guru}

Diharapkan mampu meningkatkan motivasi guru untuk mengembangkan suatu inisiatif model belajar yang lain dengan kemasan lebih menarik. Oleh karenanya pembelajaran seharusnya tidak hanya diarahkan pada pencapaian hasil belajar kognitif, melainkan kemampuan siswa secara afektif dan psikomotorik. Ini yang perlu difokuskan dan harus dipahami oleh pendidik Tentu hal ini sulit dilakukan dengan sistem belajar online karena, pendidik juga tidak mengetahui aktivitas siswa secara langsung.

\section{Bagi Siswa}

Melalui model pembelajaran sejarah berbasis wisata negeri dongeng diharapkan peserta didik dapat melakukan pembelajaran di rumah dengan antusias dan penuh tanggungjawab. Peserta didik diharapkan dapat menjalankan instruksi pendidik dengan baik walaupun tanpa di kontrol secara langsung. Harapannya peserta didik dapat mengambil makna dengan memahami peristiwa secara langsung dengan konsep model pngembangan pembelajaran serupa yang dilakukan.

\section{Bagi Sekolah}

Kepala sekolah harus bisa mengondisikan para gurunya dan peserta didik untuk tetap menjalankan proses $\mathrm{KBM}$ walaupun dengan jarak jauh dan terus mengingatkan untuk tetap mematuhi protokol kesehatan

\section{Bagi Peneliti Lain}

Diharapkan dapat mengembangkan penelitian serupa dengan penerapan model atau metode belajar berbasis kearifan local dengan tema lain yang lebih menarik. 


\section{DAFTAR PUSTAKA}

Ali Guntur dan Abdul Syukur. 2018. Tentang "Kraton Buton" Sebagai Sumber Sejarah Lokal dalam Pembelajaran Sejarah". Universitas Pattimura Ambon Jurnal Pendidikan Sejarah Vol. 7 No. 1 Januari 2018 E-ISSN : 2580 - 9180 ISSN : $2301-461 X 13$.

Andri dan I Nyoman Ruja. 2012. tentang "Pengaruh metode outdoor study terhadap kemampuan menulis karya ilmiah Geografi SMA".Jurnal Pendidikan: Teori, Penelitian dan Pengembangan. Volume: 1 Nomor: 2 Bulan: Februari Tahun: 2016.

Borg and Gall (2003:569 Borg R Walter; Gall Meredith D. 2003. Educational Research; An Intruduction, Fifth Edition; Longman

Djamarah (2002:15-16 Djamarah. 2002. Stategi Belajar Mengajar. Jakarta: Rineka Cipta.

Hamdani. M,A. 2011. Strategi Belajar Mengajar. Bandung: Pustaka Setia.

Husamah. 2013. Pembelajaran luar kelas outdoor learning. Jakarta : Prestasi Pustaka

Joyce, Weil, \& Calhoun. 2011. Models of Teaching Model-model Pengajaran. Edisi Kedelapan. Yogyakarta: Pustaka Pelajar.

Lie, A. 2004. Cooperative Learning: Mempraktikkan Cooperative Learning di Ruang-ruang Kelas. Jakarta: Grasindo.

Rochiati, Wiriatmadja. 2002. "Idealitas Pendidikan Sejarah di Indonesia: Perspektif Lokal, Nasional, dan Global”. Universitas Negeri Yogyakarta. Monograf Bandung: Historia Utama Press, 2002 ISBN: 979969730114.

Roestiyah, N. K. 2011. Strategi Belajar Mengajar Salah Satu Unsur Pelaksanaan Strategi Belajar Mengajar: Teknik Penyajian. Jakarta: Rineka Cipta

Santrock, J.W. 2007.Psikologi Pendidikan. Jakarta: Kencana.

Sapriya. 2012. Pendidikan IPS;Konsep dan Pembelajaran. Bandung: PT. Remaja Rosdakarya

Schunk, D.H. 2012. Learning Theories on educational perspective.Yogyakarta: pustaka pelajar.

Slameto (2003:13). Belajar dan Faktor-faktor yang Mempengaruhinya. Jakarta: Rineka Cipta.

Slavin, R. (2009). Coperative Learning : Teori, Riset, dan Praktik, Bandung: Nusa Media

Sudjana, N. 2012. Penilaian Hasil Proses Belajar Mengajar. Bandung: PT. Remaja Rosdakarya

Sugiyono. 2014. Metode Penelitian Kuantitatif Kualitatif dan R\&D. Bandung: Alfabeta. 